\title{
An Integrated Methodology for Construction BPR and ERP by using ARIS and UML Tool
}

\author{
Cheng-Hsien CHEN ${ }^{a}$, Yu-Cheng LIN ${ }^{\mathrm{b}}$, and H. Ping TSERNG ${ }^{c}$ \\ a Graduate Student, Department of Civil Engineering, National Taiwan Univ., Taipei, Taiwan \\ b Ph.D. Candidate, Department of Civil Engineering, National Taiwan Univ., Taipei, Taiwan Associate \\ Professor, Department of Civil Engineering, National Taiwan Univ., Taipei, Taiwan
}

\begin{abstract}
In order to improve the efficiency of construction management, a new methodology-Beauty is presented to develop translatability for construction BPR (Business Process Reengineering) and ERP (Enterprise Resource Planning) by using ARIS (Architecture of integrated Information Systems) and UML (Unified Modeling Language) tool. The Beauty method includes four phases that inclusive of business process modeling, business process reengineering, function mapping and system planning. Using Beauty method, inefficient operations within an enterprise working process can not only be identified, but also a new rational operation process can also be developed to improve efficiency. Besides, the competitive ability of a construction company is also increased. The major contribution of the Beauty method is to understand and confirm what is needed and correct process in the enterprise before running the construction ERP system. The research possibilities are identified and tested based on the implementation of the Beauty method. To some extent, this research also establishes a new agenda of process reengineering for future research.
\end{abstract}

KEYWORDS: Enterprise Resource Planning (ERP); Business Process Reengineering (BPR); ARIS; Unified Modeling Language (UML)

\section{INTRODUCTION}

\section{Research Motive}

The concept of ERP be presented that can integrate enterprise systems recently. According to Matti Hannus mention the concept that "Islands of Automation in Construction" [1]. The following figure 1 describes the automation in construction industry. Because of multi-roles joining and working in different projects will lead to the problem of information integration between projects in construction enterprise.

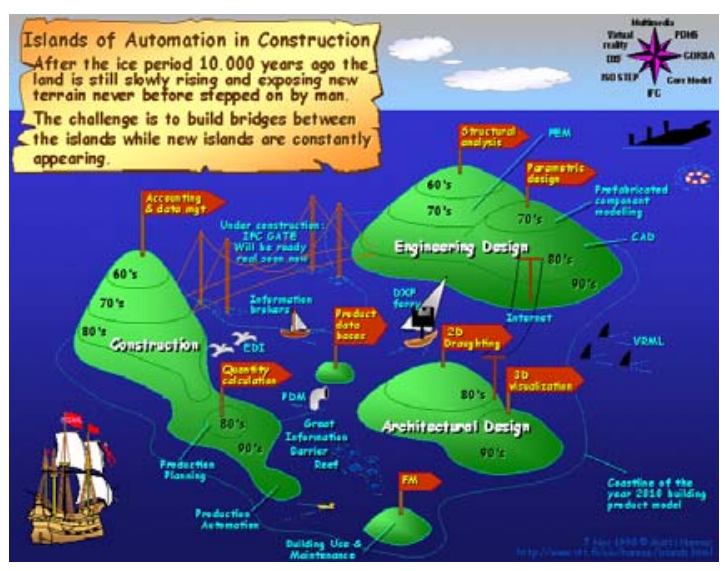

Figure 1. Islands of Automation in Construction [1]

In the past, enterprise at large implement information technology (IT) systems usually focus on single department or organization. All kinds of information systems in enterprise will come apart each other. Each information system likes an island. However, all of the information islands become independent respectively. When each department implements individual information system, each department will become individual information island. This situation will lead information flows, working flows and other flows to run between departments not smoothly. It will cause barrier and hurdle to integrate these flows each other. How to integrate flows between departments is becoming a new planning aspect by ERP system planners. Besides, according to investigation of Marina Krumbholz and Neil Maiden's research (2001) point out some problems of enterprise implements ERP system in the past [2]. Averagely, the cost increased more than 1.78 times, and the time wasted more than 1.5 times of enterprise's anticipation when implementation period. Another investigation points out the cases of enterprise implementation ERP system had $96.4 \%$ failure in the past [3]. The most serious situation leaded enterprise to close down.

Productivity in construction industry is project-based. When general contractor wants to implement ERP system. We must consider the productive pattern from project-based sites in contractor. This is a characteristic in construction industry. We want to make the implementation ERP system and business process more match and enhance the performance of ERP system. In ERP implementation process, there is a big problem existing for a long time. It is that enterprise employees know about how business processes operated in enterprise, but they don't know how to develop system planning; In 
other words, ERP system planners know about how system planning developed, but they don't know about business processes in their customers (enterprises). Therefore, when both roles cooperate to implement ERP system in enterprise will not make enterprise processes and system planning more match. This research will try to solve this big problem to avoid implementing ERP system failure. Because of enterprise implementation ERP system is time-wasted and cost-expensively that we expect to implement it in enterprise more successfully.

\section{Research Objective}

This research is focus on how to implement ERP system in construction industry and how to construct a transformation method between business processes and ERP system. It can become a consideration method when enterprise will implement ERP system. The following figure 2 illustrates the research objective.

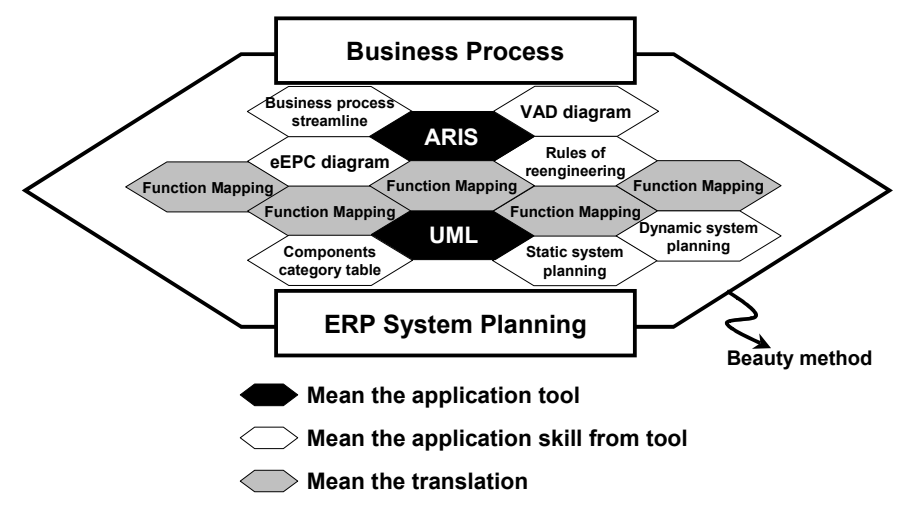

Figure 2. Honeycomb structure diagram of research objective

\section{Research Limitation and Scope}

This research is based on business process reengineering (BPR) and enterprise resource planning (ERP). This research methodology named "a integrated methodology for BPR and ERP by using ARIS and UML to construct Translatibility, Beauty methodology". In figure 3, a whole procedure of implementation ERP system will include "BPR", "Integration" and "build up ERP system" three parts. Because of page limitation, the "build up ERP system" part won't illustrate. So we use duck color to show in figure 3 . We just can illustrate "BPR" and "Integration" two parts in this paper.

\section{PROBLEM STATEMENT}

Via the above mention about feature of construction industry, the most important purpose in this research is that how to improve information advancement in construction enterprise by implementing ERP system. In table 1, we compile problem definition, description and solution of information apart in construction industry. Combining BPR and ERP regards as a total solution of enterprise information apart. In sum, BPR and ERP are concepts; Build up ERP system is a practice. In table 1, it classifies about the concepts of ERP and the practices of ERP. The following is classified:

1. Regarding the concept of ERP.

(1) Confirm goals of enterprise.

(2) Analyze and define needs of enterprise.

(3) Evaluate main business processes.

(4) Analyze original business processes.

(5) Design better business processes.

2. Regarding the practice of ERP.

(1) Match business processes with ERP system modules.

(2) Develop system implementation planning.

(3) Start to system planning.

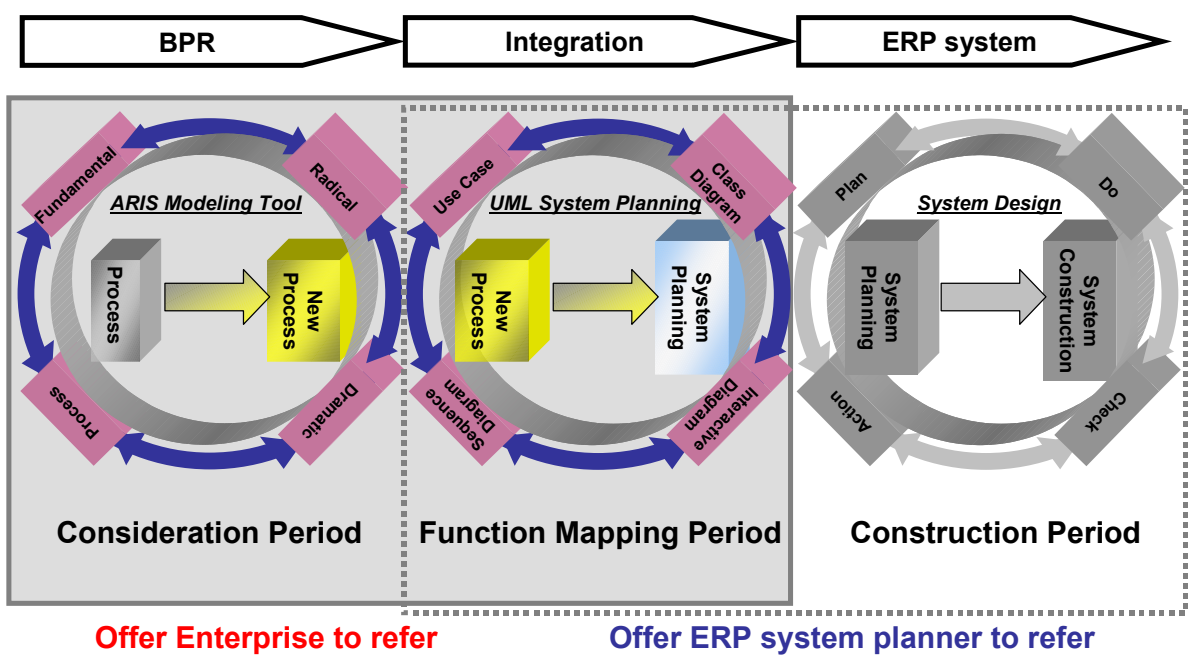

Figure 3. Research scope diagram 
Table 1. Problem definition, description and solution

\begin{tabular}{|c|c|c|c|c|}
\hline Problem & $\begin{array}{l}\text { Problem } \\
\text { Definition }\end{array}$ & & Problem Description & Solution \\
\hline \multirow[t]{2}{*}{$\begin{array}{c}\text { Information } \\
\text { Aspect }\end{array}$} & \multirow{2}{*}{$\begin{array}{l}\text { How to improve } \\
\text { information } \\
\text { advancement in } \\
\text { construction } \\
\text { enterprise by } \\
\text { implementation } \\
\text { ERP system? }\end{array}$} & $\begin{array}{l}\text { Regarding } \\
\text { the concept } \\
\text { of ERP }\end{array}$ & $\begin{array}{l}\text { Confirm goals of enterprise } \\
\text { Analyze and define needs of enterprise } \\
\text { Evaluate main business processes } \\
\text { Analyze original business processes } \\
\text { Design better business processes }\end{array}$ & \multirow[t]{2}{*}{$\begin{array}{l}\text { Business processes modeling } \\
\text { and reengineering } \\
\text { Business processes and } \\
\text { system planning integration } \\
\text { System planning }\end{array}$} \\
\hline & & $\begin{array}{l}\text { Regarding } \\
\text { the practice } \\
\text { of ERP }\end{array}$ & $\begin{array}{l}\text { Match business processes with ERP } \\
\text { system modules } \\
\text { Develop system implementation } \\
\text { planning } \\
\text { - Start to system planning }\end{array}$ & \\
\hline
\end{tabular}

Via the above mention about the concept of ERP and the practice of ERP, we can comprehend and find out the problem solutions below:

1. Business processes modeling and reengineering.

2. Business processes and system planning integration.

3. System planning.

\section{ERP IMPLEMENTATION}

\section{METHODOLOGY}

\section{Structure of Beauty Methodology}

In Beauty method, it will use ARIS and UML two modeling tools. The most important is that how to translate business processes to system planning. In figure 4 , the left dotted block includes BPM and BPR phases. These two phases will mainly use ARIS tool to proceed to business process discussion. The middle dotted block includes function-mapping phase. The phase will mainly develop the translatability between business process and system planning. The right dotted block includes system-planning phase. The phase will mainly use UML tool to proceed to system planning. Actually, the function-mapping is the kernel part in Beauty method because it build up the translatability. In the other words, Beauty method is like a bridge between business processes and ERP system planning.

\section{CASE STUDY OF CONSTRUCTION INDUSTRY}

\section{Business Process Modeling (BPM)}

There are four steps in this phase, include defining business process modeling scope, data collection, identifying main business processes and proceeding to business process modeling. The first step is that defining business process modeling scope. We must understand expectation of enterprise when deciding to implement ERP system. Let us know what functions of enterprise will need to redevelop. Production, marketing, human resource, $\mathrm{R} / \mathrm{D}$ and financial function will be involved in process modeling scope. The second step is that data collection. After redeveloping enterprise functions, data collection must be involved all related information, like standard operating procedure (SOP), operating documents, operating tables and history cases in enterprise (table 2).

An integrated methodology for BPR \& ERP by using ARIS \& UML tool to construct TranslatabilitY

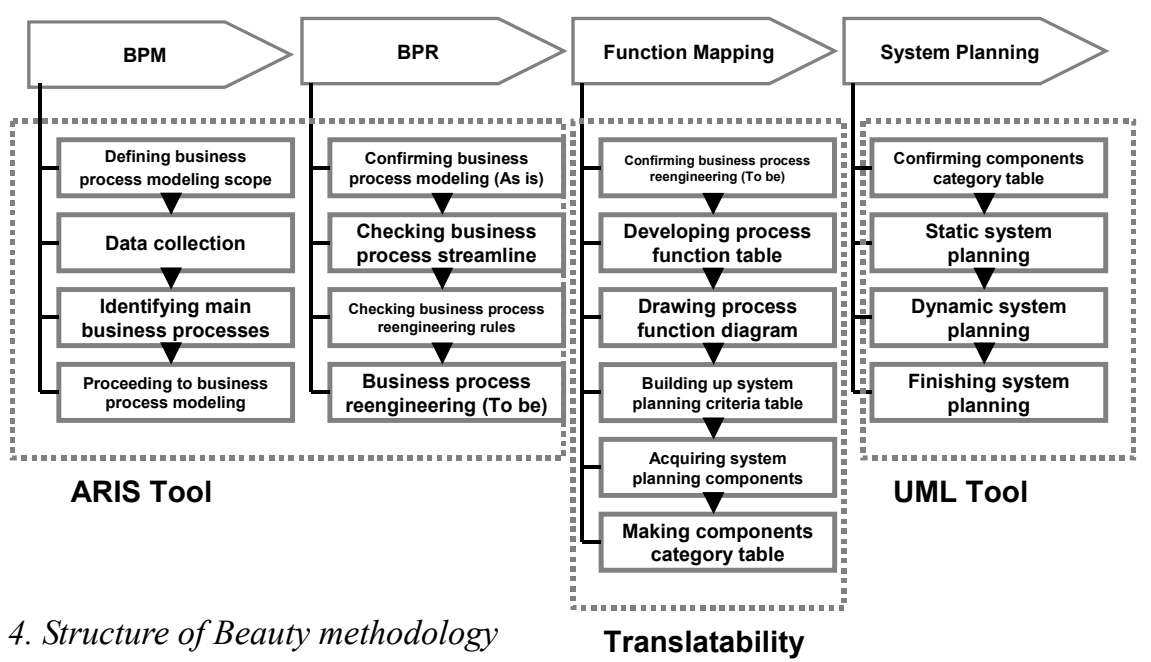

Figure 4. Structure of Beauty methodology

Translatability 
Table 2. Data collection for payment/bill process

\begin{tabular}{|c|c|c|c|}
\hline Department: & Engineering dept. & Manager: & Project Manager \\
\hline Process: & \multirow{2}{*}{\multicolumn{3}{|c|}{$\begin{array}{l}\text { Project payment and bill process } \\
\text { When project had finished in a milestone, Subcontractor } \\
\text { had to ask for project engineer to charge regularly. }\end{array}$}} \\
\hline Explanation: & & & \\
\hline \multicolumn{4}{|c|}{ Relative Information } \\
\hline & Have & & Haven't \\
\hline \begin{tabular}{|l|} 
Enterprise \\
Department \\
Structure \\
Diagram
\end{tabular} & V & & \\
\hline \begin{tabular}{|l|} 
Standard \\
Operating \\
Procedure
\end{tabular} & V & & \\
\hline \begin{tabular}{|l|}
$\begin{array}{l}\text { Project } \\
\text { Planning } \\
\text { Report }\end{array}$ \\
\end{tabular} & V & & \\
\hline
\end{tabular}

When data collection step gets ready, we can enter the third step that identifying main business processes. We must confirm main processes of enterprise. In this step, we use VAD diagram of ARIS tool to express main processes in enterprise (Fig 5). It is initial process showing in ARIS tool. When VAD diagram is finished, we

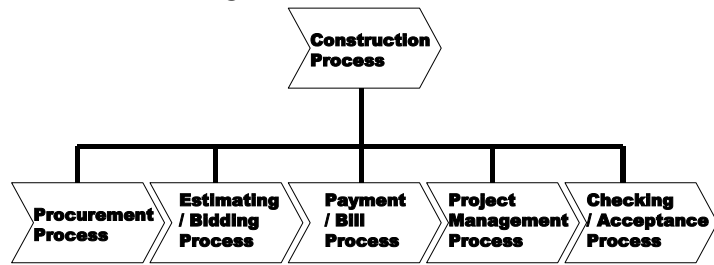

Figure 5. Main processes by VAD diagram

can enter the fourth step that proceeding to business process modeling. First, we develop process investigation table to know start activity, end activity, term activity, activity explanation, each activity related staffs, each activity input data and output data (Table 3). Second, we develop eEPC diagram to show investigation business process on the other way. It is a detail process showing in ARIS tool. In fig 6, first activity finished and passes on to second activity. There are what staffs related, what data be used by staffs and how the second activity be succeeded to the output event. eEPC diagram let us know about what staffs, activities, datum and events will be related in business process clearly.

\begin{tabular}{|c|c|c|c|c|}
\hline \multicolumn{5}{|c|}{ Started staff at first activity: Cost control staff } \\
\hline Activity name & Explanation & Related staff & Input data & Output data \\
\hline $\begin{array}{l}\text { Check amount } \\
\text { of bill }\end{array}$ & $\begin{array}{l}\text { Check the } \\
\text { amount of } \\
\text { bill from } \\
\text { contractor or } \\
\text { sub } \\
\text { contractor }\end{array}$ & $\begin{array}{l}\text { Project } \\
\text { engineer }\end{array}$ & $\begin{array}{l}\text { Bills from } \\
\text { subcontractor }\end{array}$ & $\begin{array}{l}\text { The amount } \\
\text { of number } \\
\text { and money of } \\
\text { tables }\end{array}$ \\
\hline $\begin{array}{l}\text { Fill up } \\
\text { evaluation } \\
\text { tables }\end{array}$ & \begin{tabular}{|l} 
According to \\
output data \\
above, fill up \\
evaluation \\
tables
\end{tabular} & $\begin{array}{l}\text { Project } \\
\text { engineer }\end{array}$ & $\begin{array}{l}\text { The amount } \\
\text { of number } \\
\text { and money of } \\
\text { tables }\end{array}$ & \begin{tabular}{|l|} 
Evaluation \\
tables
\end{tabular} \\
\hline $\begin{array}{l}\text { First time to } \\
\text { verify } \\
\text { evaluation } \\
\text { tables }\end{array}$ & $\begin{array}{l}\text { Project } \\
\text { manager will } \\
\text { verify } \\
\text { evaluation } \\
\text { tables }\end{array}$ & \begin{tabular}{|l|} 
Project \\
manager
\end{tabular} & \begin{tabular}{|l|}
$\begin{array}{l}\text { Evaluation } \\
\text { tables }\end{array}$ \\
\end{tabular} & $\begin{array}{l}\text { The first time } \\
\text { Verified } \\
\text { evaluation } \\
\text { tables }\end{array}$ \\
\hline $\begin{array}{l}\text { Second time to } \\
\text { verify } \\
\text { evaluation } \\
\text { tables }\end{array}$ & \begin{tabular}{|l} 
Engineering \\
director will \\
verify \\
evaluation \\
tables
\end{tabular} & $\begin{array}{l}\text { Engineering } \\
\text { director }\end{array}$ & \begin{tabular}{|l} 
The first time \\
Verified \\
evaluation \\
tables
\end{tabular} & $\begin{array}{l}\text { The second } \\
\text { time Verified } \\
\text { evaluation } \\
\text { tables }\end{array}$ \\
\hline & & & & \\
\hline
\end{tabular}

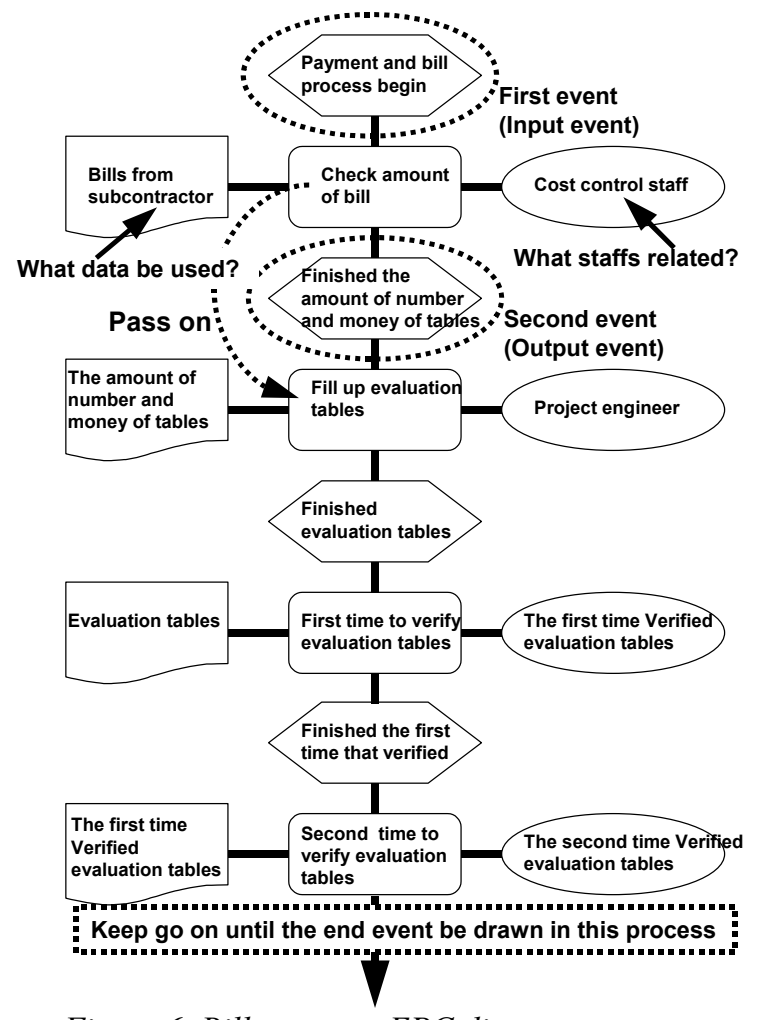

Figure 6. Bill process eEPC diagram

\section{Business Process Reengineering (BPR)}

There are four steps in this phase, include confirming business process modeling (As is), checking business process streamline, checking business process reengineering rules and business process reengineering (To be). The first step is that confirming business process modeling (As is), when we finished business process modeling phase above paragraph. We must discuss with related staffs to confirm the correctness of process investigation table and eEPC diagram. The second step is that checking business process streamline, we will focus on checking the rationality of streamline. We develop five cases of process streamline styles (Table 4). Table 5 is that explanation of five cases. For example, if process streamline strike across many departments or staffs. Maybe it means that some departments or staffs aren't necessary to be strike across. So we have to reduce unnecessary departments or staffs to make process streamline more simplify. Besides, we must check rules of business process reengineering to eliminate unreasonable activities in process. The third step is that checking business process reengineering rules which include to refer to combination similarly activities, reducing unnecessary examine or supervise works, learning from other successful enterprise business process and automation of some activities in business process to reduce human effects. When we finished from the first to the third phases, we can make business process reengineering (To be). 
Redevelop original business process to become new business process. Absolutely, there are new process investigation tables, eEPC diagrams and business process streamlines will be developed.

Table 4. Five cases of process streamline

\begin{tabular}{|c|c|c|c|c|c|c|c|c|}
\hline${ }_{\text {Activity }} \begin{array}{l}\text { Dep. } \\
\text { IStaff }\end{array}$ & $\begin{array}{l}\text { Dep. } \\
\text { Staff } \\
1\end{array}$ & $\begin{array}{l}\text { Dep. } \\
\text { /Staff } \\
2\end{array}$ & $\begin{array}{l}\text { Dep. } \\
\text { / Staff } \\
3\end{array}$ & $\begin{array}{l}\text { Dep. } \\
\text { IStaff } \\
4\end{array}$ & $\begin{array}{l}\text { Dep. } \\
\text { IStaff } \\
5\end{array}$ & $\begin{array}{l}\text { Dep. } \\
\text { IStaff } \\
6\end{array}$ & $\begin{array}{l}\text { Dep. } \\
\text { IStaff } \\
7\end{array}$ & \begin{tabular}{|c} 
Dep. \\
IStaff \\
8
\end{tabular} \\
\hline Activity A & & I & & & & & & \\
\hline Activity B & & I & & & & & & \\
\hline Activity C & & & & & & & & \\
\hline Activity D & & & : & & & & & \\
\hline Activity $\mathrm{E}$ & & & I & & & 1 & & \\
\hline Activity $\mathrm{F}$ & & & $\therefore$ & & & $\cdot$ & & \\
\hline Activity G & & & & & & & & \\
\hline
\end{tabular}

Gray column means that unnecessary strike across

Table 5. Explanation of five cases

\begin{tabular}{|l|l|l|}
\hline Cases & \multicolumn{1}{|c|}{ Type } & \multicolumn{1}{|c|}{ How to modify? } \\
\hline Case 1 & $\begin{array}{l}\text { This streamline is running in the } \\
\text { same dep. Istaff from start to end. }\end{array}$ & $\begin{array}{l}\text { It's well streamline, doesn't } \\
\text { need. }\end{array}$ \\
\hline Case 2 & $\begin{array}{l}\text { This streamline is striking across two } \\
\text { dep. /staff or upward. }\end{array}$ & $\begin{array}{l}\text { Reducing unnecessary dep. } \\
\text { Istaff. }\end{array}$ \\
\hline Case 3 3 & $\begin{array}{l}\text { This streamline is striking across two } \\
\text { dep. Istaff or upward. And it comes } \\
\text { back some dep. Istaff reduplicated. }\end{array}$ & $\begin{array}{l}\text { Reducing unnecessary dep. } \\
\text { Istaff and avoiding some } \\
\text { dep. Istaff reduplicated. }\end{array}$ \\
\hline Case 4 & $\begin{array}{l}\text { This streamline is striking across two } \\
\text { dep. Istaff or upward. And it comes } \\
\text { back some activities reduplicated. }\end{array}$ & $\begin{array}{l}\text { Reducing unnecessary dep. } \\
\text { Istaff and avoiding some } \\
\text { activities reduplicated. }\end{array}$ \\
\hline Case 5 & $\begin{array}{l}\text { This streamline is striking across two } \\
\text { dep. Istaff or upward. And it comes } \\
\text { back some dep. Istaff and activities } \\
\text { reduplicated. }\end{array}$ & $\begin{array}{l}\text { Reducing unnecessary dep. } \\
\text { Istaff and avoiding some } \\
\text { dep. Istaff and activities } \\
\text { reduplicated. }\end{array}$ \\
\hline
\end{tabular}

Function Mapping

There are six steps in this phase, include confirming business process reengineering (To be), developing process function table, drawing process function diagram, building up system planning criteria table, acquiring system planning components and making components category table. The first step is that confirming business process reengineering (To be). We inherit from the result of BPR phase. We must discuss with related staffs to confirm the correctness of new process investigation tables, eEPC diagrams and business process streamlines. The second step is that developing process function table. We classify the result of BPR phase to become "event", "function", "organization" and "data" four categories according to investigation table, eEPC diagram and process streamline (Table 6).

Table 6. Process function table

\begin{tabular}{|c|c|c|c|c|c|}
\hline \multicolumn{6}{|c|}{ Process function table } \\
\hline Activity & Function & Organization & Input data & Output data & Event \\
\hline 1 & $\begin{array}{l}\text { Check amount } \\
\text { of bill }\end{array}$ & $\begin{array}{l}\text { Cost control } \\
\text { staff }\end{array}$ & $\begin{array}{l}\text { Bills from } \\
\text { subcontractor }\end{array}$ & $\begin{array}{l}\text { The amount of } \\
\text { number and money } \\
\text { of tables }\end{array}$ & $\begin{array}{l}\text { Make the amount of } \\
\text { calculating tables }\end{array}$ \\
\hline 2 & $\begin{array}{l}\text { Fill up } \\
\text { evaluation } \\
\text { tables }\end{array}$ & Project engineer & $\begin{array}{l}\text { The amount of } \\
\text { number and } \\
\text { money of tables }\end{array}$ & Evaluation tables & Make evaluation tables \\
\hline 3 & $\begin{array}{l}\text { First time to } \\
\text { verify evaluation } \\
\text { tables }\end{array}$ & Project engineer & Evaluation tables & Evaluation tables & Verify evaluation tables \\
\hline 4 & $\begin{array}{l}\text { Second time to } \\
\text { verify evaluation } \\
\text { tables }\end{array}$ & \begin{tabular}{|l|}
$\begin{array}{l}\text { Project } \\
\text { Manager }\end{array}$ \\
\end{tabular} & $\begin{array}{l}\text { The first time } \\
\text { Verified } \\
\text { evaluation tables }\end{array}$ & $\begin{array}{l}\text { The second time } \\
\text { verified evaluation } \\
\text { tables }\end{array}$ & Verify evaluation tables \\
\hline 5 & Keep go on & Keep go on & Keep go on & Keep go on & Keep go on \\
\hline - & - & - & & - & • \\
\hline • & • & • & - & - & - \\
\hline - & - & - & - & - & - \\
\hline
\end{tabular}

When we develop process function table at the ready. The third step is that drawing process function diagram. We draw function, data, event and organization four diagrams according to process function table. For example, fig 7 and fig 8 are function and data models.

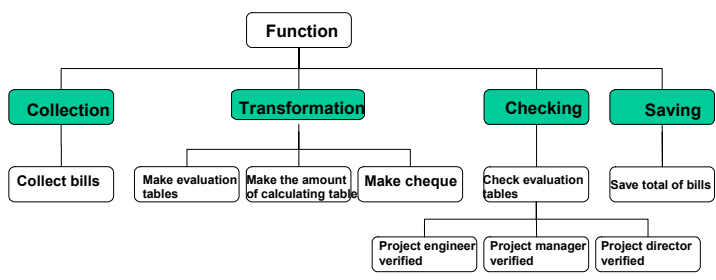

Fig 7: Function model from process function table

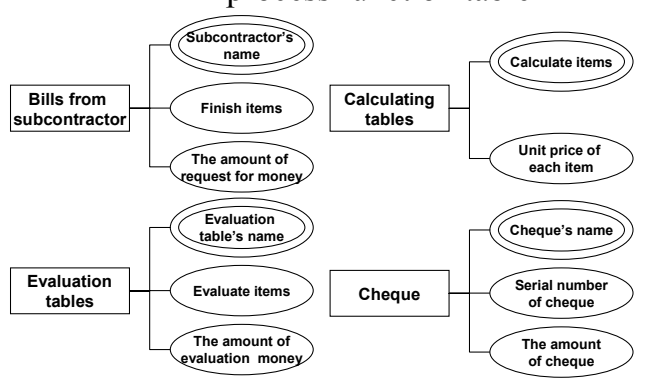

Figure 8. Data model from process function table

The fourth step is that building up system planning criteria table. We transform process function table, event model, function model, organization model and data model into system planning criteria table. This step is critical point that transforms business process (using ARIS tool) into ERP system planning (using UML tool). In the other words, we can say it is important referring to system planning successfully. The fifth step is that acquiring system planning components. We try to acquire useful components from the results of the second to the fourth steps before UML system planning. After acquisition, we can make components category table at the sixth step to prepare for system planning phase (Table 7).

Table 7. Components category table

\begin{tabular}{|c|l|}
\hline $\begin{array}{c}\text { System planning } \\
\text { components by UML tool }\end{array}$ & Outcome of acquisition from ARIS tool \\
\hline Actor & Department or staff \\
\hline Use-Case & $\begin{array}{l}\text { Process name, event, entity or } \\
\text { information }\end{array}$ \\
\hline Class Name & Department's name, staff or entity \\
\hline Attribute & $\begin{array}{l}\text { Attribute (eg. Subcontractor's name, } \\
\text { evaluation table's name etc.) }\end{array}$ \\
\hline Operation & $\begin{array}{l}\text { Attribute (eg. The motion of verify, the } \\
\text { motion of calculate etc.) }\end{array}$ \\
\hline Message & $\begin{array}{l}\text { Information (eg. Subcontractor } \\
\text { finished a part of project etc.) }\end{array}$ \\
\hline
\end{tabular}




\section{System Planning}

There are four steps in this phase, include confirming components category table, static system planning, dynamic system planning and finishing system planning. The first step is that confirming components category table. We must discuss with related staffs to confirm the correctness. The second step is that static system planning. We develop static system planning according to rules of UML tool. The core work of static system planning is that develop "Use-Case diagram", "Use-Case description", "Object diagram", "Class diagram" and "Class description". A complete static system planning will have a lot of diagrams and descriptions by use-case, object and class planning. For example, fig 9 and fig 10 are one of use-case diagrams and one of class diagrams. The third step is that

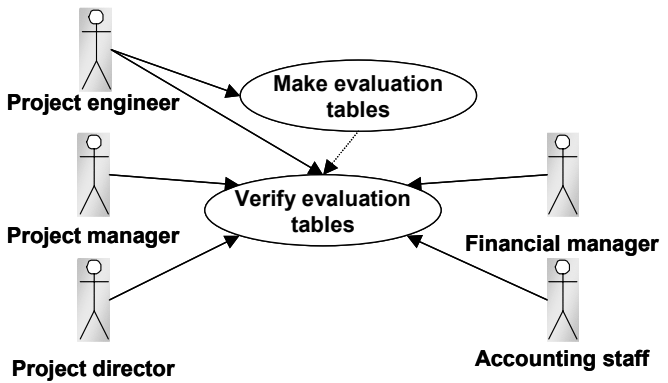

Figure 9. Use-Case diagram ofmaking evaluation tables

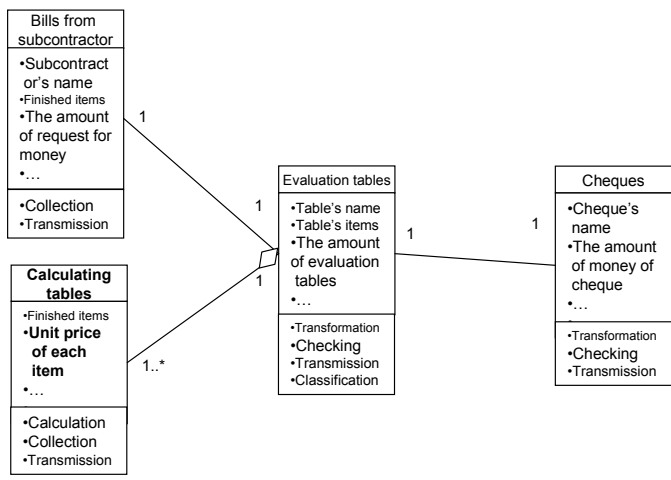

Figure 10. Class diagram of makingpayment/bill process

dynamic system planning. We develop dynamic system planning according to rules of UML tool. The core work of dynamic system planning is that develop "Collaboration diagram", "Sequence diagram", "State diagram" and "Activity diagram". A complete dynamic system planning will have a lot of diagrams by collaboration, sequence sate and activity planning. For example, fig 11 and fig 12 are one of sequence diagrams and one of activity diagrams.

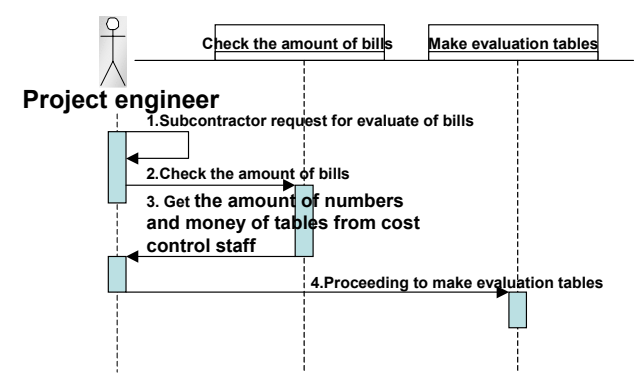

Figure 11. Sequence diagram ofmaking evaluation tables

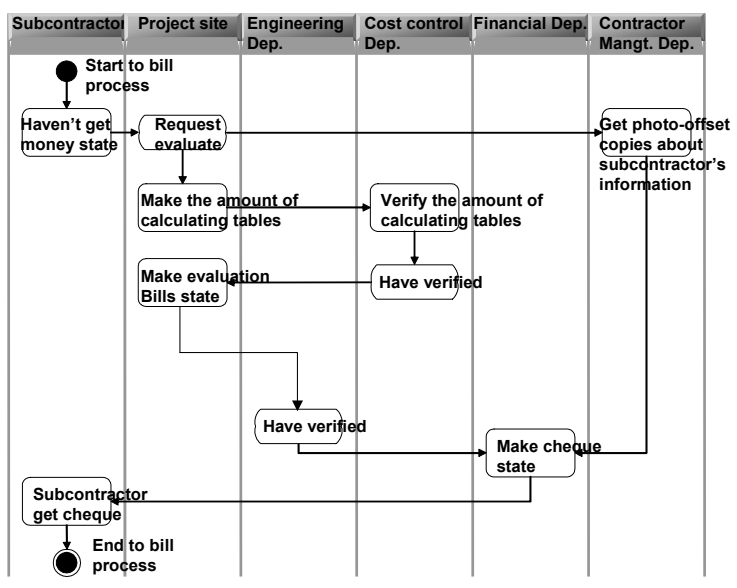

Figure 12. Activity diagram of making bill process

The fourth step is that finishing system planning. In the static system planning and the dynamic system planning steps, we will develop hundreds or thousands of tables and diagrams. We must discuss with related staffs to confirm the correctness. After confirming the correctness about UML models of static and dynamic system planning, we have finished to translate enterprise business processes into system planning. The result will be taken for the specification by ERP system planning company. In sum, we build up the four phases and hope to help enterprise implement ERP system more successfully.

\section{CONCLUSION}

Enterprise implements ERP system almost failure as a result of existing a gap between enterprise employees and ERP system planners. The gap is that they don't understand the other side affairs each other. Beauty method tried to solve this problem. Enterprise applies Beauty method before ERP system implementation will make business processes to appropriately. Using ARIS model will eliminate unnecessary activities and staffs. Using UML model will make system planner more understand what ERP system enterprise needs. In sum, combining ARIS and UML model to translate business processes into system planning will make ERP system implementation more successfully. 


\section{REFERENCE}

[1] http://cic.vtt.fi/hannus/islands.html

[2] Marina Krumbholz and Neil Maiden (2001) "The Implementation of enterprise resource planning packages in different organizational and national cultures" Information Systems Vol.26, p185-204.

[3] AI-Mashari M. (2000) "Constructs of process change management in ERPContent: A focus on SAP R/3" AMCIS p977-980. 